\title{
Marx on Commodites,Contradictions
} and Globalisations Resources for a Critique of Marketised Culture

\author{
Graham Murdock' \\ Loughborough University
}

\begin{abstract}
When the Soviet Union collapsed, proponents of the new neo liberal economic order were quick to consign Marx's ideas to the dustbin of history. This judgement has proved altogether too hasty and recent years have seen a major revaluation of his analysis and its applicability to contemporary conditions. This paper identifies three strands in Marx's political economy of capitalism that remain central to a critical interrogation of the present situation: his analysis of commodity fetishism, his insistence that capitalist expansion is driven by an unstoppable drive to globalise its organising logics and principles; and his recognition that this impetus generates contradictions that provide the basis for opposition and resistance. Building on these insights this paper sets out to accomplish two tasks. Firstly, to show how successive developments in popular media and consumption have successively consolidated and thickened the commodity culture that underpins the new empire of capitalism. Secondly, to identify the new contradictions set in motion by the system's increasing dependence on communications networks with global reach.
\end{abstract}

Key Words: media, consumption, Marxism, commodities, capitalism expansion, globalisation, contradiction

\footnotetext{
1 Graham Murdock is Reader in the Sociology of Culture at the Loughborough University. His main interests are in the Sociology and Political Economy of Culture. He is author of Communication and Critical Inquiry (Sage 2006), The Battle for Television (Palgrave Macmillan 1994), co-author of Television Across Europe: A Comparative Introduction (Sage 2000), Communicating Politics: Mass Communications and the Political Process (Holmes \& Meier Publishers 1987), among many others. His current work is on advertising and on the social impact of new communications technologies.
} 
Resumo: Quando a União Soviética entrou em colapsou, proponentes da nova ordem neoliberal rapidamente lançaram as idéias de Marx na lixeira da história. Este julgamento se provou de todo precipitado, e os anos recentes testemunharam uma grande revalidação de suas análises e sua aplicabilidade para as condições contemporâneas. Este trabalho identifica três linhas da economia política de Marx que continuam centrais para uma interrogação crítica da situação atual: as suas análises do fetichismo da mercadoria; sua insistência de que a expansão capitalista é dirigida por um impulso irrefreável de globalizar suas lógicas e seus princípios organizadores; e o reconhecimento de que este ímpeto gera contradições que fornecem as bases para oposição e resistência. Com base nestes insights, este trabalho se propõe a cumprir duas tarefas. Primeiramente, mostrar como sucessivos desenvolvimentos na mídia e no consumo popular consolidaram e incrementaram a cultura da mercadoria que corrobora o novo império do capitalismo. Em segundo lugar, identificar as novas contradições postas em movimento pelo fato de o sistema depender crescentemente de redes de comunicação de alcance global.

Palavras-chave: mídia, consumo, marxismo, mercadorias, expansão do capitalismo, globalização, contradição.

\section{Marx Our Contemporary}

In 1965, the Polish literary critic, Jan Kott, published Shakespeare Our Contemporary, proposing that the plays were more relevant to the circumstances of Soviet rule than to the situation Shakespeare himself had faced. Marx's work is currently undergoing a similar revaluation. From being dismissed as a figure rendered obsolete by the fall of the Berlin Wall he is now seen as a key resource for confronting contemporary conditions. As Francis Wheen argues, in his recent commentary on Capital, 'Marx may 
only now be emerging in his true significance [and] could yet become the most influential thinker of the twenty first century' (Wheen 2006: 121) I want to support this claim and argue that a properly critical analysis of the cultural landscape of present-day capitalism must begin by engaging with three central themes in Marx's writing - commodification, contradiction., and globalisation. This is not to argue that Marx provides definitive answers to present problems in cultural research. To look for certainties is to ignore the unfinished and provisional nature of his work and to disregard his own favourite motto, De omnibus dubitandum - 'You must have doubts about everything'. Rather he offers us essential starting points and resources that we can mobilise and build on.

\section{The Commodification of Almost Everything}

At first sight it seems odd that Marx should choose to begin the opening chapter of his magnum opus, Capital, with a chapter on commodities since, as he notes, "a commodity appears... a very trivial thing, and easily understood" (Marx 1946: 41) But, for him appearances are deeply deceptive. Concealed within the commodity are the essential clues to the way capitalism operates as both a mode of social organisation and an ideological formation. The true history of commodities and the source of their value Marx argued "does not stalk about with a label describing what it is". It is written in a "social hieroglyphic" that requires decoding. Attempting "to decipher the hieroglyphic, to get behind the secret of our own social products" is therefore a central task for critical analysis (Marx 1946: 45).

In The Poverty of Philosophy, an early draft of his core ideas, written in 1847, Marx identifies commodification as the central driving force propelling capitalism's expansion. Future profits he argued, require every available resource to be converted into a good or service that can be sold for a price in the marketplace. The decisive break with the feudal past is marked by the arrival of "a time ... when the very things which till then had been communicated, but never exchanged; given but, never sold; acquired, but never boughtvirtue, love, conviction, knowledge, conscience, etc- finally passed into commerce... when everything, moral or physical. ...is brought to the market" (Marx 1976: 113). The main 
capacity 'brought to the market' was for Marx, labour power, and it was this process, and its consequences, that lay at the heart of his mature analysis.

Following previous political economists (including Adam Smith and Ricardo) he argues that the value of a commodity reflects the amount of labour that has gone into producing it. As workers move from the modes of self sufficiency and barter supported by rural economies to industrial production they become commodities themselves. They are forced to sell their labour power for a wage that will allow them to purchase the food, clothing and other goods they need to keep themselves fit for employment and able to nurture next generation of workers. For Marx, these 'socially necessary' costs of labour are met by the value produced in only part of the working day. The rest of the time generates additional or 'surplus' value that employers can appropriate as profit. This structure of exploitation is the dirty secret buried within every commodity. Beneath the appearance of equal exchange and honest dealing in the marketplace - a fair day's wage for a fair day's work, a useful product for a reasonable price - lies the near slavery of the sweatshop and relentless regimentation of the factory clock and machine production. The promise of utility, convenience and pleasure held out by the goods displayed in shops concealed the hard realties of the everyday struggle for subsistence.

\section{The Contradictions of Capitalist Expansion}

This structure was not as solid as it seemed however since for Marx the very processes that ensured ever rising rates of productivity generated contradictions that chipped away at their foundations. Firstly, the more efficient production became the more likely it was that a crisis of over production would occur with goods piling up unsold, setting in motion a highly unstable cycle of boom and bust Secondly, bringing workers together in large industrial plants and housing them in densely packed neighbourhoods capital created social spaces in which they could recognise their shared conditions and organise to change them. Borrowing from his favourite novel, Mary Shelley's Frankenstein, he argued that just as Baron von Frankenstein's desire to manufacture a perfect life form produced a monster who tuned on his creator so capitalism's dedicated quest to maximise profits produced the conditions for its destruction. The appearance of uninterrupted 
progress was deceptive. The more areas of social and imaginative life capitalism invaded the more it produced the conditions for the formation of workers' movements led by vanguard parties who could illuminate the situation and organise a disciplined revolutionary response.

Marx however miscalculated the extent to which the expansion of capitalism would be accompanied by an expanded state apparatus prepared to intervene to head off economic crisis and social unrest by intervening in market dynamics through regulatory regimes and public investments. After prolonged struggles workers' movements won significant concessions on minimum wages, working hours, health and safety at work, holiday entitlements, pensions, and employment protection. At the same time, states in advanced capitalist countries embarked on substantial programmes of public investment in education, health, housing, and work creation. By compensating for market failures in guaranteeing minimal standards and universal entitlements these interventions held out the promise of tangible improvements to working people. States also made decisive contributions to capitalism's stability through their sustained investment in military capacity. Marx did not foresee how crucial public spending welfare and warfare would be for the growth of advanced capitalism. Nor did he anticipate the continuing centrality of nationalist ideologies in cementing a sense of shared fate. He never fully recognises the importance of populist appeals to patriotism and the imagined community of the nation in weakening class consciousness. He was however absolutely correct in seeing the fetishism of commodities as central to capitalism's success in covering its own tracks

\section{Deceptive Surfaces: Commodity Culture}

In religious belief systems a fetish is any object or image believed to have magical or supernatural powers. As a Jewish boy who had grown up in Trier, a mainly Catholic city that had only been reincorporated into a Protestant Prussian state three years before he was born, he was well aware of the power often attributed to religious relics, statues and images. For him, commodities operated in the same way. Once on display, they took on a life of their own and were invested with the power to change lives. The early professional advertisers, who were developing their key sales techniques just as Capital was finally 
published, recognised the potency of appeals to transformation immediately. Borrowing from Christian evangelical movements they promoted the healing touch of commodities, promising that consumers could be born again and enjoy a life of comfort, peace and satisfaction. Dirt would be banished by proprietary cleaning fluids, bodily ailments addressed by patent medicines, and domestic drudgery abolished by labour saving machines "All that was required was one single choice" (Loeb 1994: 184). This appeal to consumerism - the belief that consumption is the primary space of freedom and self expression - proved enormously effective as an ideological system for three reasons.

Firstly, advertising and other forms of product promotion are carefully designed to project attention forwards, celebrating the pleasures of possession and use and silencing awkward questions about the organization of production. Consumers are encouraged to think about what commodities will do for them and to forget to ask where they have come from, who produced them under what conditions, and what social and environmental costs were incurred in assembling them. This distancing of use from origins was steadily reinforced as mechanised mass production removed all marks of human labour and the growth of national road and railways systems and transnational steam ship lines steadily increased the distances commodities travelled from their point of origin to their eventual market, making it more and more difficult to recall how and where they were made. This absence was increasingly addressed by the rise of branded goods bearing the manufacturer's name. As Lord Randolf Churchill, observed at time, "We live in....in the age of Holloway's Pills, of Colman's Mustard, and of Horniman's pure tea" (quoted in Richards 1991: 249). The effect was to transfer credit for their production from Labour to Capital.

Secondly, the proliferation of purchasable commodities operated to validate the belief in 'progress' that underpinned industrial capitalism's model of modernity. Improvements to the material base of public life-Street lighting, sewage systems, new transport networks - provided one highly visible index of the benefits delivered by capitalism's appropriation of invention. The domestic conveniences, comforts and consolations delivered by manufactured commodities anchored this process firmly in the intimacies of domestic life. These two modes of legitimation were welded together to 
spectacular effect at the Great Exhibition of 1851, held first in London's Hyde Park and later at the Crystal Palace in a southern suburb. The architects used the new technologies of steel and glass to construct the first wholly modern cathedral of capitalism and the organisers packed it with contemporary inventions and commodities of all kinds. It was "a display of ...perverted ingenuity on an unprecedented scale" in which useful objects jostled for attention with commodities of dubious value, like the corset that 'opened instantaneously in case of emergencies', but the overall message was clear; "the world was full of wonderful objects that you couldn't live without" (Stevenson 2006: 21) made possible by the inventiveness of scientists and engineers and the entrepreneurial spirit of the new capitalists.

Thirdly, it was no accident that the new world of goods displayed at the Great Exhibition should be housed in a building that became a major destination for day trippers and tourists. There was a powerful connection between the new consumption and the new leisure. The department stores that "emerged slowly and unevenly between 1850 and 1890" (Benson 1986: 13) offered their patrons entertainments as well as opportunities to shop and were part of a cityscape increasingly filled with restaurants, theatres, dance halls, music venues and exhibits adapted to a variety of tastes and incomes. These new opportunities for enjoyment and relaxation lay at the heart of the pragmatic bargain struck between capital and labour. Industrialised work might by dirty, dangerous, monotonous and alienating but the wages earned provided the chance to exercise individual choices and personal expression during 'free' time. .In this conception the pleasures of consumption and leisure appeared as rewards for the rigours of labour. From a relatively early point in its development however, the modern consumer system involved new forms of labour.

\section{Leisure as Labour}

In 1916, the American entrepreneur, Clarence Saunders, opened his Piggly Wiggly, store in Memphis Tennesse, reputedly named after the children's nursery rhyme, 'This Little Piggy Went to Market'. It was the world's first self service store, and the blueprint for the modern supermarket. Department stores were staffed by sales assistants who advised shoppers on the qualities of the various goods on offer .Often they also provided a free 
home delivery service. Customers entering the Piggly Wiggly passed through a turnstile ,walked around aisles piled high with branded goods, took their purchases to a check out till ,carried them away on foot, by urban transport systems or, increasing , by car, and once home stored them in refrigerators. It was a system designed to transfer the labour involved in comparing rival goods, transporting them and storing them, from producers to consumers. The promised convenience of this new style of shopping came with substantial social and economic costs. It is this notion of leisure as labour that Dallas Smythe developed so productively in his 'Blindspot' article.

In his analysis of the "audience commodity" Smythe argues that what television advertisers are buying from commercial broadcasters is viewers' attention and receptiveness to the ads. Far from the ads interrupting the programmes, the programmes serve as a prelude and accompaniment to the ads. Like the "potato chips and peanuts given to customers of the pub bar, or cocktail lounge," they offer a "free lunch" designed to keep people relaxed and receptive (Smythe, 1981: 37-8). For Smythe, the pleasures of looking and the exercise of "audience power" (Smythe 1981:26) are mobilised primarily to oil the wheels of people's never-ending labour of "marketing consumer goods and services to themselves" (Smythe 1981: 34). Domestic space becomes an extension of the factory assembly line, subject to the industrialised regimes of time and motion written into broadcasting schedules. This novel application of Marx's analysis of labour was taken a step further by two other North American writers, Sut Jhally and Bill Livant, who argued that in the same way that profits in production come from "surplus labour", so profits in the commercial broadcasting system come from the "surplus watching time" undertaken after the viewing time required to cover costs has been completed (Jhally and Livant 1986: 127). In their hypothetical example, audiences only have to watch four of the twelve ads in a half-hour show to meet its costs. Their attention to the remaining eight is pure profit.

This analysis was presented by Smythe and his supporters, not simply as a useful extension to critical political economy's analysis of commercial broadcasting but as a necessary change of direction since in their view "mass media are not characterised primarily by what they put into audiences (messages) but by what they take out (value)" (Jhally and Livant 1986: 143). By posing the issue in this way, they reinforce the formidable 
perimeter fence that divides critical political economy from cultural analysis. I have never accepted this bifurcation. Since all forms of mediated communication are always, simultaneously, symbolic formations and economic systems, critical analysis has to be a matter of both/and not either/or.

Consequently, if we are to engage with the contemporary applications of the full range of Marx's commentary on commodities it is necessary to grapple with questions of ideology, which is where Western Marxism still has much to offer.

\section{Accounting for Reversal}

The generalisation and Americanisation of consumer culture was not the only pivot of change in post-war Western Europe. A shift in the politics of the Left was also gathering momentum. Coalitions were developing outside the traditional Left parties and the trade union movement. This new impetus exploded onto the streets in 1968 and for a brief time it looked as though the solid looking structures of power would be subverted by a new spirit of dissent and liberation. But the moment came and went and within a few years Margaret Thatcher and Ronald Reagan were leading a fundamentalist revival of neoliberal economics, dismembering the public sector and installing market forms of enterprise and evaluation across every sector of social activity, including the cultural and media industries. For those caught up in the 'events' of 1968 this rapid reversal of fortune had strong echoes in an earlier period.

In the aftermath of World War I unrest and insurrection had swept across Europe. After the dust had settled the only enduring shift in power had occurred in Russia which many commentators of the time saw as the least promising site for an overthrow of the old order. Not only were socialist and communist movements turned back everywhere else, but within a few years Fascist governments had come to power in Germany and Italy. Not surprisingly, accounting for this spectacular reversal became a major preoccupation among Marxist theorists living to the west of the borders established by the new Soviet Union. The search for explanations launched by these 'Western Marxists', led by the 'Frankfurt School' and Antonio Gramsci, spread out in a number of directions, but the analysis of 
ideology and popular compliance increasingly assumed a key role. Re-reading Marx's on commodities and commodifiction was and remains central to this effort.

\section{Looking, Hoping, Possessing: Landscapes of Desire}

As young man of twenty four Marx had ridiculed a German author who claimed that the veneration of religious fetishes raises man above his sensuous desires and saves him from being a mere animal. Far from transcending sensuous desire "Marx riposted fetishism is the religion of sensuous desire: 'Fantasy arsing from desire deceives the fetishworshipper into believing that an inanimate object will give up its natural character in order to comply with his desires"' (Wheen 2006: 43). He never returned to this argument in his later work however .In Capital he remarks in passing that human wants may "spring ...from fancy" (Marx 1946: 1) but it was left to Western Marxists, strongly influenced by Freud to explore the cultural construction of demand and desire. For Walter Benjamin the fetishism of commodities had a strong sensuous and erotic dimension .It was a process of redirecting "desire and passion towards lifeless manufactured products.... [through which] the commodity is transformed into an object of sexual desire, and to consume is to consummate this desire" (Gilloch 1996: 120). In this conception, moving through the world of commodities was no longer simply a secular form of religious devotion, it was a series of intimate encounters with objects charged with some of the same erotic intensity that devotees of sexual fetishes might derive from rubber clothing or high-heeled shoes. And as with sexual fetishism the pleasures of the new consumer landscape were as much about looking as about possession.

This new landscape revolved around two major poles, the mobilisation of innovations in mass media for advertising and promotion and the construction of new retail environments. Together they constructed a new landscape of desire that embraced both places and spaces, urban planning and imagination. As Figure 1 shows each major development in retailing was accompanied by the rise of a new central medium of popular communication which, in combination, reorganised consumption around a new central principle. This was not a process of cancellation however. Each new stage contained and incorporated previous stages. 
Figure 1 The Consolidation of Commodity Culture

\begin{tabular}{|lcc|}
\hline Key medium & key retail environment & central principle \\
Newspapers & traditional shops & Utility \\
Cinema & department stores & Display \\
Commercial & supermarkets & Flow \\
Television & mega malls & Convergence \\
Interactive & theme parks & \\
Media & & \\
\hline
\end{tabular}

Marx died in the 1880s just as commodity culture was on the point of a major shift. The topography he was familiar with was still dominated by classified newspaper advertisements promoting individual products grouped into basic categories and traditional shops specialising in a particular range of commodities - groceries, meat, furniture, and clothing. Both were based around specialisation and separation and both paid relatively little attention to visual display. Press advertisements relied wholly or mainly on printed text and traditional shops simply placed the commodities they had to sell in the window or outside on the street. There was little or no attempt to display goods against enticing or glamorous backgrounds. Goods were judged primarily in terms of their usefulness, durability and value for money

This austerity ended in the last years of the nineteenth century. Innovative technologies of lithographic printing enabled the posters pasted up on walls and hoardings to be drenched in vivid colours while the new department stores built in major metropolitan centres, offered shoppers the chance to see everyday commodities displayed against exotic backgrounds such as Indian palaces and Turkish Harems. This emphasis on display also became a ruling principle in the organisation of domestic space. The Protestant Ethic, which Max Weber identified as the psychic driving force of capitalist expansion, operated in the sphere of consumption as well as production. For the evangelical Protestants who led the push to industrialise in the early Nineteenth century continual reinvestment in productive capacity was matched by severe strictures on pleasure in private life. Increased productivity was a mark of grace and the rejection of ostentation was a 
demonstration of godliness. With the steady rise in prosperity in the 1860s and 1870s however, this attitude shifted and "wealth became a signifier for "goodness" [and] possessions the visible proof of one's success and respectability' (Wulf, 2006:10). Among the affluent middle classes the preoccupation with maintaining living standards gave way to the search for a life style that would express one's moral character. Manufacturers were only too happy to support this quest to demonstrate individual worth through consumer choices and interior decoration. 'One company offered 7,000 varieties of bedsteads, while another furniture maker stocked 300 different side-boards, which ranged from gothic to Moorish styles' (Wulf, op cit).

This new emphasis on display was further extended in the early years of the twentieth century as department stores spread to provincial towns and the new medium of cinema became a fixture on every high street.

The new stores took full advantage of innovations in glass and lighting technologies to fill the large windows that fronted onto the street with theatrically lit displays in which commodities featured as the central characters in a variety of scenes. The cinema extended this dramatisation of goods in action. By 1920, Will Hays, the man appointed to censor the erotic excesses of Hollywood, was in no doubt that film offered a potent advertisement for American capitalism and the American way of life carrying "to every American at home, and to millions of potential purchasers abroad, the visual, vivid perception of American manufactured products" (Eckert 1978: 5). But it was the novelist Scott Fitzgerald, in one of his short stories, who recognised how indelibly demand was shaped by desire. His young heroine, Yanci, sits in a movie theatre, completed immersed in images of desirable objects and sensuous styles. Watching the star "Mae Murray swirl through splendidly imagined vistas, she calculated the cost of the apartment. She rejoiced in the beauty of Mae Murray's clothes and furs, her gorgeous hats, her short-seeming French shoes" (quoted in Fuller, 1996:162). The connections between looking, wishing and possessing were cemented together by a series of devices. Manufacturers paid to have their goods featured in films in pioneering instances of product placement and promotional tieins transferred the aura of the screen to the stores that surrounded cinemas in town centres. The publicity pack that accompanied the release of Now Voyager (1942), a film that 
celebrates a dull spinster's transformation into a woman of elegance and sophistication, for example, urged local clothing outlets to devise "special windows showing travelling ensembles and accessories" under the slogan "Now Voyager, Buy Wisely...Now!” (quoted in La Place 1987: 142).

Going to the cinema, visiting a department store, of simply going into town to 'window shop', all required effort and planning however. They were events, time taken out of mundane routines. In contrast commercial broadcasting was part of the flow of everyday household life. It domesticated consumer culture, moving it from public to private space. As Frank Arnold, an early American enthusiast of commercial radio, noted in 1931, "for the first time in the history of mankind" it is possible to enter "the homes of the nation through doors and windows, no matter how tightly barred," and to deliver "the message of advertising [into] the midst of the family circle, in moments of relaxation" (quoted in Smulyan, 1994:87). Commercial television extended this selling proposition by adding visuality to the intimacy of radio. Despite the regulators best intentions, the new medium's promotional impetus could not be confined to the designated advertising breaks. It spilled out across the entire schedule. Whatever the type of programme "the effect was a visual, visceral dazzle, an absorbing sense of pleasure in the act of perusal...Things to look at. New things. The latest things" (Marling, 1994:5). The screen became a "shop window, the box a warehouse" and "every prop" was "purchasable" (Conrad, 1982: 122). Viewers were constructed as consumers twice over, as audiences for the endless parade of goods and styles on display in the programmes and as potential purchasers of the commodities promoted in the advertisements.

In explicit contrast to the American model of commercialism Britain had developed a public service model of broadcasting implemented through a single monopoly programme supplier, the BBC, and paid for out of public taxation. Established in the aftermath of World War 1, when the prospect of social divisions and unrest preoccupied the political Establishment, public service broadcasting set out to cement the nation and support responsible citizenship. But against the odds, in 1955, Britain became the first country in Western Europe to introduce commercial television when a Conservative government bowed to business lobbying and opened the way for advertising funded 
services. The new system was initiated in London and spread rapidly across the main population centres. Despite the public service obligations imposed on the new operating companies, programming was markedly more populist from the outset. It set out to tap into popular tastes and personal aspirations. In a country that had only recently emerged from a long period of post war austerity, and where food and clothing had remained rationed for some years, the displays of abundance and style in the ads and the surrounding programmes seemed to be full of new possibilities. Viewers were addressed not as citizens or workers but as consumers. Appeals to the solidarities of labour and the reciprocities of citizenship, with their injunction to contribute towards the common good, were displaced by a discourse of individual redemption through purchases. This invitation to affluence found a ready audience as rising real wages transformed the struggle to maintain basic living standards into a search for a life style. The social contract that had elected a Left of centre government after the War was steadily dissolved in the warm ideological bath of consumerism. The figure of the worker, particularly the unionised worker, came increasingly to represent backwardness and disruption. The new heroes of advancement were heroes of consumption, with the rising celebrities of television playing an increasingly important role. Their on screen personas, lavish houses, and glamorous leisure activities came to epitomise the rewards of consumption. In the stock exchange of styles they acted as universal investment advisors. The American personalities, featured in imported commercial programming operated as an advanced guard. Programmes like I Love Lucy held out the promise of attainable transformations built around car ownership, new household appliances, stylish clothes, and an appetite for enjoyment. It was a sign of times to come as the transition, from a culture of citizenship to a culture of consumption, was later replicated across Western Europe and the emerging economies of India and China.

The growth of commercial television in the 1950's was accompanied by the rapid expansion of a new kind of retail environment the supermarket. The organising principle of both was flow. Just as viewers moved through carefully structured schedules designed to keep them tuned to the channel by moving them from one programme to another, the new shopping environments required then to navigate their way around the whole store to purchase the range of goods they required. Watching commercial television replicated to 
experience of orchestrated consumption entailed in walking up and down the supermarket aisles. The supermarket however was soon to be displaced by the mall.

The idea of a covered pedestrian area containing a number of separately owned and run shops was not in itself novel. The glass covered Burlington Arcade which opened in London in 1819 had provided a model that was adopted throughout Europe .These new structures were 'passages' covered walkways running between two streets By the 1930s however they appeared very much as part of a vanishing past prompting the German critic Sigfried Kracauer to write a, 'Goodbye to the Linden Arcade' and Walter Benjamin to embark on a massive project in cultural archaeology devoted to the Paris arcades Fittingly, in an ear when the pivot of empire was passing from Europe to the United States, the mall was an American innovation. The Southdale Centre, the first fully enclosed and covered mall, opened in Elina, Minnesota, in 1956, but it was another Minnesota town, Bloomington, which developed the mall's full potential in 1992 with the first mega mall, Mall of America .Alongside the myriad retail outlets it contained a theme park, ice rink, movie theatres, restaurants, and three hotels. By combining multiple consumption and leisure choices in one thermostatically controlled and internally policed environment it created a classic total institution. It promised patrons that there was no need to go anywhere else because everything one could possibly need was right there, within easy reach. The mall was not a passageway leading to somewhere else. It was the final destination. This principle of converging entertainment and shopping opportunities was replicated in another environment that combined spectacle and sales in novel ways-the theme park.

It was reproduced in domestic space by a commercial television environment irreversibly altered by the introduction of multiple cable channels and the advent of 24 hour programming. In the United Sates the major networks, who had dominated television since its introduction, saw their share of the audience steadily decline. In Europe cable and satellite channels broke the monopoly hold of the public service broadcasters in country after country. The result was a commodity culture more fully integrated than ever. Mega malls provided multiple entertainments as well as shopping opportunities. Cable television packages offered home shopping channels alongside film, sports, and entertainment 
services. Television programming escaped from domestic space and was projected onto giant screens in public spaces or relayed into bars and restaurants. At the same time, increasing reliance on corporate sponsorship and product placement multiplied the paidfor opportunities to integrate commodities into programming.

This sense of being immersed in a borderless landscape of consumption has been intensified by the rise of the Internet and the increasing use of web sites for product promotion. Digital media accelerate the convergence of spectacle and selling. They also intensify the personalisation of consumer experience. Individuals jump between hyperlinks in eccentric patterns and are hailed on the screens of their computers and mobile phones by ads that seem to be talking directly to them.

It is this new totalising culture of consumption that is now rapidly gaining ground across the globe. As Leslie Sklair has argued, 'Global capitalism thrives by persuading us that the meaning and value of our lives are to be found principally in what we possess, that we can never be totally satisfied with our possessions (the imperative of ever-changing fashion and style), and that the goods and services we consume are best provided by the free market" (Sklair 2002: 6). It is only in the last twenty years however, with the collapse of the Soviet Union and the shift from state economic management to market oriented policies in India and China, that this vision has been implemented across all the world's major economic zones.

\section{The New Empire of Capital}

In a wonderfully prescient passage in the Communist Manifesto Marx and Engels argue that the logic of capitalism impels it towards global reach. Driven by the constant need to expand markets they argued, it must chase "over the whole surface of the globe" and "nestle everywhere, settle everywhere, establish connections everywhere" breaking down the barriers thrown up by "local and national seclusion and self-sufficiency" wherever they were encountered (Marx and Engels 1968: 38-39). They saw two possible cultural consequences of this process. Their optimistic reading imagined a new cosmopolitan world culture as increasing contact and "intercourse in every direction" generated a new "universal inter-dependence " and converted "the intellectual creations of 
individual nations" into "common property". But they also saw very clearly that the possibilities for creative exchange were subordinated to the logic of domination though which capitalism "compels all nations, on pain of extinction, ...to introduce what it calls civilisation into their midst" and to refashion themselves "after its own image" (op cit: 39). Throughout the twentieth century this process was spearheaded by a vision of consumer culture manufactured in the United States.

In 1898 the American financial journalist and presidential advisor, Charles Conant, argued in a hugely influential article that solving the problem of over production in the American economy required a strong commitment to a policy of 'economic imperialism' in which the US would reach "out for command of new markets" in Asia and Africa and compete with the European powers to "raise the underdeveloped portions [of the world] as far as may be to the level of comfort... and civilization of the more advanced portions" (Conant 1899: 608). The 'soft power' exercised by consumer culture's 'ability to entice and attract' played a pivotal role in this battle to globalise the American Way (Nye 2002: 8) As the New York journalist, Charles Merz, argued in 1926 , the global ascendancy of Hollywood was a far more effective weapon in the global contest for competitive advantage than territorial annexation:

Trade no longer follows the flag. It follows the film...The moving picture has achieved, unwittingly, what different Powers in different times have built navies, levied taxes, intrigued, coerced, and slaughtered in order to achieve. ...Automobiles manufactured here are ordered abroad after screen shadows have been observed to ride in them; China wants sewing machines; rich Peruvians but pianoplayers; order come from Japanese who have admired mission armchairs in the films (Merz 1926:159-165).

At the same time, the decolonisation movements that were gathering momentum across the territorial empires of the old European powers were presenting themselves as champions of authentic national cultures and demanding the control of collective fate conferred by independent statehood. After prolonged struggles to secure political autonomy the post-colonial regimes that emerged after World War II embarked on a sustained process of nation-building aimed at mapping the imagined communities of collective life onto the boundaries of the newly constituted states. Developing shared infrastructure and communal resources took priority over personal desire. Official 
nationalisms emphasised austerity, self-denial, and the postponement of personal choice in consumption. This ethos was reinforced on a daily basis by state run public broadcasting services that enlisted viewers behind the banners unfurled by essentialist constructions of national traditions and culture and celebrations of model workers and citizens who had exceeded the call of collective duty. It is this 'nation building' model of modernity that has been systematically dismantled and displaced by the onwards march of marketisation over the last fifteen years.

For most of the second half of the Twentieth century this impetus was interrupted by the uncoupling of the world's three largest economic arenas - China, India and the Soviet Union - from the global capitalist system. In the last twenty years however the world wide enthusiasm for market solutions has now finally confirmed Marx and Engels' vision. A new global empire of capital based not on territorial conquest but on the ascendancy of marketised culture has emerged.

The world wide celebration of markets and consumption has been fuelled by an increasing disillusion with state ownership and central planning. Undermined by corruption, inefficiency, and unresponsiveness to popular demand, public initiatives came to be seen as barriers rather than agents of 'progress', a perception reinforced by the collapse of the Soviet Union. Some governments have embraced market driven alternatives with enthusiasm and zeal, others have been forced to implement 'structural reajustments' as a condition of loans from international banks or agencies or membership of the World Trade Organisation. As a result, there is now no major economic zone that is not incorporated into the world capitalist system and subject to its ruling ideology of consumerism.

This pattern has steadily spread to countries where the cultural landscape was previously entirely or strongly state directed, including China, where there is now sufficient disposable income among the new rich and rising the middle class to support the world's largest shopping mall, the Golden Resources, in Beijing, opened in 2004. A similar landscape is under construction in the world's other emerging major economic power, India, where it carries a powerful ideological charge. As one Indian journalist notes, "Malls 
have become urban India's homage to "progress", communicating a great sense of reassurance that if the mall is large enough and has enough brands, all is well with the world" (Rao 2005). Identifying the future with increasing opportunities for consumption and life style choice has steadily undermined the collective vision of nation building that drove post independence 'development'. Personal satisfactions now take priority over public investments and communal facilities.

As with the first wave of capitalist expansion however, this latest phase is simultaneously generating new contradictions and providing new means to mobilise opposition.

\section{Networked Contradictions}

The globalisation of capitalism has been highly uneven in both its development and impacts.

Firstly, there has been a rapidly growing divide between the winners and losers in this process. For every hi-tech hub and creative quarter there are continually sprawling shanty towns and slums. For every expanding town and city there is a depopulated countryside. For every corporate headquarters and research facility housing highly rewarded executives and experts, there is an 'offshore' sweatshop, call centre, or factory employing workers on the minimum possible wage. For every business traveller and tourist there is a wave of migrant labourers and asylum seekers.

Secondly, it is now clear that industrial expansion has imposed cumulative and irreversible environmental costs that are also unequally distributed. The strip mining and deforestation entailed in maintaining supplies of essential raw materials and foods has been located mainly in low income countries or regions. When their 'useful;' life is over the pollution embedded in the standard components of washing machines, television sets, personal computers, mobile phones, and other consumer items has been transported out of city centres and suburbs and dumped in remote rural areas or on the outer edges of cities. 
These inequalities have created a proliferating global population of the exploited, dispossessed and humiliated In common with many Victorian social commentators, Marx drew a sharp distinction between the labouring poor and the floating population of 'lumpen proletariat' moving from job to job. The former were the raw material for revolution, the latter a problem to be controlled. Under current conditions, this distinction no longer holds. In response to the globalisation of exploitation and destitution we see the globalisation of potential responses.

One reaction has been the resurgence of religious and national fundamentalisms reasserting the purity and uniqueness of communities of belief and territory. But a second alternative is also in the process of formation, based on a philosophy of cosmopolitan citizenship and demanding the implementation of social justice on a global scale .Ironically, it is commodity culture that has provided one of the most effective arenas for mass mobilisation behind this project. The consumer boycotts of goods made by child labour or involving environmental despoilation, the rising demand for more effective recycling of discarded goods and packaging, and the growing support for Fair Trade produce, are indicators of a shift in sensibilities in capitalism's affluent centres. But the real struggle is yet to come. The challenge of global warming will require not simply more ecologically informed modes of consumption but a substantial scaling down. The struggle for popular consent to this readjustment will centre on the new global networks of communication.

Capitalism has always relied on advanced communications systems to track, collate, and co-ordinate the dispersed production and consumption activities it sets in motion. In the first phase of expansion these tasks were accomplished by the technologies of the telegraph, and later the telephone and the punched card machine. Now they depend on the convergence of computing, telecommunications and cultural production made possible by the conversion of all form of expression - text, data, voice, recorded sound, still and moving images - into the single universal language of 0 's and 1's. This process of digitalisation has created networks of unparalleled reach and capacity. Struggles over how much of this capacity will be open to the public, how public networks will be organised, who will have access to them, how, and for what purposes, will be major points of conflict in the coming decades. 
The stakes in this struggle are already clear from the skirmishes now taking place over the Internet. There are two very different models of networking currently in play. On the one side we see an explosion of peer-to-peer exchange based on horizontal networks in which every participant is a potential producer of original content as well as a consumer of material produced elsewhere. These exchanges are underpinned by an ethos of reciprocity in which contributors post their material to be freely used in the expectation that others will offer their contributions in turn. This principle has already generated a series of major interventions The Open Source Movement has constructed a range of collaborative written and freely available software (most notably, the Linux operating system) that is more robust and reliable than the proprietary alternatives offered by Microsoft and other commercial producers. The Wiki movement has produced Wikipedia, the world's most comprehensive encyclopedia compiled entirely by volunteers. The best of the on line commentaries and diaries, blogs, written by experts, journalists and members of the public, have become essential supplements to professionally crafted news and commentary. By revealing aspects of events hidden from or missed by professional news photographers and film crews the digital photographs and video footage taken by amateurs, and posted on file-sharing sites, offer a more complete first draft of history. Bulletin boards allow voices excluded from the mainstream media to find an audience.

On the other side however, we see corporate interests devoting a great deal of energy to commandeering public networks in the service of promotion and profit. Users are tracked every time they click on a hyperlink and their progress across the Net logged and collated to provide detailed consumer profiles that can be used to personalise promotional appeals more effectively. The imaginary social spaces created by the participants in multi user on-line games become sites for the construction of virtual stores by real off-line retail chains. Contributors to film and music sites run by fans and enthusiasts are enlisted as viral marketers, promoting a new release by word of mouth. As we noted earlier, Marx saw the logic of capitalism continually bringing to the market "things which till then had been communicated, but never exchanged; given but never sold" (Marx 1976:113). The commercial annexation of the Net is a perfect instance of this process in action. 
Faced with this concerted push and with the increasingly immersive quality of commodity culture it is tempting to see the main business of radical political economy as demolishing the facile utopianism of the more naïve internet enthusiasts and developing a comprehensive inventory and critique of the formidable new weapons in capitalism's ideological armoury. This is certainly necessary but it is not sufficient. Marx's ambition was to develop an analysis of capitalism that offered not only a critical analysis of its logics and consequences but also resources for change. Our present task is to develop a comprehensive critique of globalised consumerism and its impacts and to work towards an alternative grounded in a working philosophy of cosmopolitan citizenship. The first step is to develop practical proposals for creating the institutional anchors that will secure a global network of popular communication capable of delivering the basic resources for understanding and action that will implement these principles across the full range of everyday experience.

\section{References:}

Benson, S.P (1986) Counter Cultures: Saleswomen, Managers and Customers in American Department Stores,1890-1940. Urbana. University of Illinois Press.

Collier, Andrew (2004) Marx. Oxford. One World Press.

Conant, Charles A (1899) 'Can New Openings be Found for Capital?', The Atlantic Monthly, Vol 84, Issue 505, pp 600-609.

Conrad, P (1982) Television: The Medium and its Manners. London. Routledge and Kegan Paul.

Eckert, C (1978) ‘The Carole Lombard in Macy's Window’, Quarterly Review of Film Studies, 3 (1), 1-21.

Fuller, K H (1996) At the Picture Show: Small-Town Audiences and the Creation of Movie Fan Culture. Washington DC. Smithsonian Institute Press.

Gilloch, G (1996) Myth and Metropolis: Walter Benjamin and the City. Cambridge: Polity Press.

Jhally S and Livant B (1986) 'Watching as Working: The Valorization of Audience Consciousness', Journal of Communication, 36 (3), Summer, pp 124-143.

Loeb, L.A (1994) Consuming Angles: Advertising and Victorian Women. Oxford: Oxford University Press. 
Marling, K A (1994) As Seen on TV: The Visual Culture of Everyday Life in the 1950s. Cambridge MA. Harvard University Press.

Marx, K (1946) Capital: A Critical Analysis of Capitalist Production-Volume One. London: George Allen and Unwin.

Marx ,K and Engels, F (1976) Collected Works-Volume Six. New York. International Publishers.

Marx, Karl and Engels, Frederick (1968) Selected Works in One Volume. London. Lawrence and Wishart.

Merz, Charles (1926) ‘When the Movies Go Abroad', Harpers, January, pp 159-165.

Nye, Joseph S.Jr (2002) The Paradox of American Power: Why the World's Only Superpower Can't Go it Alone. New York. Oxford University Press.

Rao. Geeta (2005) 'Mall and Supermalls' http://www.hinduonnnet.com/the hindu/mp/2055/06/11/stories/2005061103190300.htm [accessed August 25 2006]

Richards, T (1991) The Commodity Culture of Victorian England: Advertising and Spectacle, 1851-1914. London.Verso

Sklair,Leslie (2001) The Transnational Capitalist Class. Oxford Blackwell Publishing.

Smythe, D W (1981) Dependency Road: Communications ,Capitalism, Consciousness and Canada. Norwood NJ : Ablex.

Stevenson, J (2006) 'Power to the People', The Observer: Review , August 13,2006, p 21

Wheen, F (2006) Marx's Das Capital: A Biography. London. Atlantic Books.

Wulf, Andrea (2006) 'When priests chose the curtains', The Guardian: Saturday Review, $4^{\text {th }}$ November, $p 10$. 